\title{
Electrochemical Performance of the Porous Nickel Anode in the Molten Carbonate Fuel Cell
}

\author{
Göran Lindbergh and Mari Sparr \\ Department of Chemical Engineering and Technology, Applied Electrochemistry, \\ Kungliga Tekniska Högskolan, SE-100 44 Stockholm, Sweden
}

(Received November 20, 2000)

\begin{abstract}
In this study, stationary polarisation curves were obtained for a porous nickel electrode under varying temperatures and anode gas compositions. The exchange current densities were determined from the slopes of the polarisation curves at low overpotentials, i.e. the assumption was made that the porous electrode is under kinetic control. The outlet gas compositions were measured by analysis in a gas chromatograph. The gases were found to be far from equilibrium. However, almost the same reaction orders were found independently of the assumptions of gas compositions but they were rather high and therefore difficult to explain by the generally assumed mechanisms.
\end{abstract}

\section{INTRODUCTION}

In a fuel cell, chemical energy in a fuel is continuously and directly converted to electrical energy by means of electrochemical reactions taking place on the anode and the cathode. Several fuel cell types are under development, differing in operating temperature and materials used for electrolyte and electrodes. The molten carbonate fuel cell (MCFC) operates at a high temperature $\left(600-700^{\circ} \mathrm{C}\right)$, which gives it the potential to reach high overall electrical efficiency $(50-60 \%)$ in an integrated system. It is generally operated using natural gas as its fuel, although it can also operate with high concentrations of carbon monoxide and carbon dioxide in the fuel, making it very suitable for use with biogas or gasified biomass feeds.

The MCFC is step by step coming closer to commercialisation, with several large units in the $\mathrm{MW}$ scale demonstrated during the last years. The state-ofthe-art technology consists of an in-situ oxidised porous nickel oxide cathode, a porous nickel anode and a lithium-potassium or lithium-sodium carbonate melt as electrolyte. Both the cathode and the anode are so called gas diffusion electrodes, made up of larger pores for gas transport, smaller pores filled by molten alkali carbonate and a solid electron conducting electrode matrix. The reactants are transported into the electrode in the gaseous phase, dissolved in the melt and reacted at the electrode surface.

Operation of MCFC with biogas or biomass will result in much lower concentrations of hydrogen gas in the fuel. Therefore it is of interest to investigate the performance of the anode under such conditions. The overvoltage losses at the anode are considered to be relatively small, which partly is due to the relatively low current densities that present MCFC systems are operating at. A significant increase in this, which is desirable in order to improve the power density, would result in increase of losses at the anode. Operating with lower concentration of hydrogen is also expected to increase the losses at the anode.

A general procedure when elucidating the mechanism of the anode reaction is to determine the reaction orders for the components $\left(\mathrm{H}_{2}, \mathrm{CO}_{2}\right.$ and $\left.\mathrm{H}_{2} \mathrm{O}\right)$ that are involved in the overall electrochemical reaction. 


$$
\mathrm{H}_{2}+\mathrm{CO}_{3}^{2-} \leftrightarrow \mathrm{H}_{2} \mathrm{O}+\mathrm{CO}_{2}+2 \mathrm{e}^{-}
$$

Several studies have been made to find out the reaction mechanism at the anode, Table 1. Most experiments were conducted on flag electrodes, which are quite different from porous electrodes, regarding electrode material and mass transfer conditions. Though a lot of research has been done the reaction mechanism is still not well known.

A problem when evaluating the reaction orders is to know the gas composition inside the cell since other reactions can take place at the anode. Carbon monoxide can be oxidised electrochemically.

$$
\mathrm{CO}+\mathrm{CO}_{3}^{2-} \leftrightarrow 2 \mathrm{CO}_{2}+2 \mathrm{e}^{-}
$$

Another possible reaction is the shift reaction, which is the electrically neutral sum of reaction (1) and (2).

$$
\mathrm{H}_{2}+\mathrm{CO}_{2} \leftrightarrow \mathrm{H}_{2} \mathrm{O}+\mathrm{CO}
$$

According to Borucka and Appleby /19/ the reaction rate for direct $\mathrm{CO}$ oxidation is extremely slow at $99.99 \%$ pure gold. They claimed that the most likely way for the $\mathrm{CO}$ to be utilised is through the shift reaction that has been reported to be established rapidly $120 \%$.

In this study, stationary polarisation curves were obtained for the porous electrode under varying anode gas compositions at 600,650 and $700^{\circ} \mathrm{C}$. The slopes of the polarisation curves were studied at low overpotentials and high flow rates and the exchange current densities were determined form these curves. Since it is not possible to investigate the hydrogen oxidation without interference by other reactions it is necessary to control the gas composition.

The objectives of the study are to get a better

Table 1

\begin{tabular}{|c|c|c|c|}
\hline References & Years & Techniques & Electrode \\
\hline Ang \& Sammells /1/ & 1980 & polarisation, $\mathrm{CA}$ & $\mathrm{Ni}$, Co wire \\
\hline Vogel /2/ & 1980 & polarisation & $\begin{array}{l}\mathrm{Ni}, \mathrm{Au}, \mathrm{Pt} \text { flag } \\
\mathrm{Ni} \text { membrane-porous }\end{array}$ \\
\hline Jewulski \& Suski /3/ & 1984 & calculations & \\
\hline $\begin{array}{r}\text { Lu \& Selman /4/ } \\
\qquad / 5-6 /\end{array}$ & $\begin{array}{l}1984 \\
1989\end{array}$ & $\begin{array}{l}\text { polarisation, } \mathrm{CA} \\
\mathrm{CV} \text {, calculations }\end{array}$ & $\begin{array}{l}\mathrm{Ni}, \mathrm{Cu} \text { cylinder } \\
\mathrm{Cu} \text { wire }\end{array}$ \\
\hline $\begin{array}{r}\text { Yu \& Selman } / 7 / \\
/ 8 / \\
/ 9 / \\
/ 10 /\end{array}$ & $\begin{array}{l}1984 \\
1991 \\
1991 \\
1992\end{array}$ & $\begin{array}{l}\text { calculations } \\
\text { polarisation } \\
\text { EIS } \\
\text { Calculations }\end{array}$ & $\begin{array}{l}\mathrm{Ni} \text { porous } \\
\mathrm{Ni} \text { porous }\end{array}$ \\
\hline Bieniasz \& Suski /11/ & 1988 & calculations & $\mathrm{Au} / \mathrm{Ni}, \mathrm{Co}, \mathrm{Cu} /$ \\
\hline Nishina et al. $/ 12 /$ & 1990 & EIS, CV,CC & $\begin{array}{l}\mathrm{Ni}, \mathrm{Co}, \mathrm{Cu}, \mathrm{Au}, \mathrm{Ag}, \mathrm{Pt}, \mathrm{Pd} \text {, Ir } \\
\text { flag }\end{array}$ \\
\hline $\begin{array}{l}\text { Weewer et al. /13/ } \\
\text { Weewer } / 14 / \\
\text { Weewer et al. } / 15 /\end{array}$ & $\begin{array}{l}1990 \\
1991 \\
1995 \\
\end{array}$ & $\begin{array}{l}\text { EIS } \\
\text { polarisation, EIS, CV,CA }\end{array}$ & $\begin{array}{l}\mathrm{Ni} \\
\mathrm{Ni}, \mathrm{Au}, \mathrm{Cu} \text { flag, Ni porous }\end{array}$ \\
\hline Wilemski /16/ & 1983 & calculations & \\
\hline Suski/17/ & 1997 & review article & \\
\hline Christensen \& Livbjerg /18/ & 1992 & calculations & $\mathrm{Ni}$ \\
\hline
\end{tabular}

Published work on the anode kinetics and reaction mechanisms. Experimental methods are; EIS=electrochemical impedance spectroscopy, $\mathrm{CA}=$ chronoamperometry, $\mathrm{CC}=$ chronocoulometry and $\mathrm{CV}=$ cyclic voltammetry. 
understanding of the factors that influence cell performance at the anode side, to determine the kinetic parameters of the hydrogen oxidation reaction and to obtain information about the reaction mechanism, even at low concentrations of hydrogen. The results can be used in cell and stack models for system simulations as well as for stack design.

\section{EXPERIMENTAL}

Experimental data were obtained from a $3 \mathrm{~cm}^{2}$ laboratory cell unit provided by ECN, The Netherlands. The cell consisted of a porous nickel anode alloyed with $10 \% \mathrm{Cr}$, a porous nickel cathode, that was oxidised in situ, and a $\mathrm{LiAlO}_{2}$ matrix, supporting a $62 \% \mathrm{Li}_{2} \mathrm{CO}_{3} /$ $38 \% \mathrm{~K}_{2} \mathrm{CO}_{3}$ electrolyte. The reference electrodes were gold wires submerged into the melt and in equilibrium with a $33 / 67 \% \quad \mathrm{O}_{2} / \mathrm{CO}_{2}$ gas mixture. The reference electrodes were connected to the cell via small capillaries in the cell house. All the experiments were carried out with standard cathode gas, i.e., $15 / 30 \%$ $\mathrm{O}_{2} / \mathrm{CO}_{2}$ in $\mathrm{N}_{2}$. Different anode gases were used for the experiments. In order to reduce the effect of mass transfer limitations in the gaseous phase and conversion, the gas flow rate was kept high $(245 \mathrm{ml} / \mathrm{min})$. These gases were fed into the cell after saturating them with water vapour. The anode gases were humidified at $60^{\circ} \mathrm{C}$ and the cathode gases were humidified at $30^{\circ} \mathrm{C}$. The cell temperature was varied between 600,650 and $700^{\circ} \mathrm{C}$. At each temperature, polarisation curves were obtained. In order to get cell conditions more like a real cell, where it is usually assumed that the gas has reached equilibrium, some catalyst was placed in the gas channel inlet for cell no. 1 and cell no. 3. A nickel wire netting was inserted in the gas channel for cell no.l and a commercial shift reactor was used in the same way for cell no.3.

Polarisation curves for different gas compositions were all obtained at optimal electrolyte filling by a Solartron 1286 Electrochemical Interface. For evaluation of the ohmic potential drop, the current interrupt method was used. In these measurements the overvoltage was recorded $20 \mu \mathrm{s}$ after interruption of the current.

\section{THEORY}

The exchange current densities for different fuel gases were determined on the basis of the polarisation curves. When analysing experimental data from porous electrodes it is important to take into account the current distribution along the depth of the electrode. According to Lagergren and Simonsson 122 / this could be done by the expression for the total polarisation resistance.

$\frac{d \eta}{d i}=\frac{L}{\kappa_{1}+\kappa_{2}}+\frac{L}{\sqrt{a}} \cdot \frac{1}{\kappa_{1}+\kappa_{2}} \cdot\left[\frac{2}{\sinh \sqrt{a}}+\left(\frac{\kappa_{1}}{\kappa_{2}}+\frac{\kappa_{2}}{\kappa_{1}}\right) \cdot \operatorname{coth} \sqrt{a}\right]$

$a=\frac{\mathrm{L}^{\hat{2}} \mathrm{FSi}_{0} \mathrm{n}}{\mathrm{RT}} \cdot\left(\frac{1}{\mathrm{~K}_{2}}+\frac{1}{\mathrm{~K}_{1}}\right)$

The equation has asymptotic equations that may be found for the two limiting cases, when $a$ approaches zero and infinity. With the assumption that $a$ is large and that the electrodes effective conductivity $\kappa_{1}$ is much higher than the pore electrolyte conductivity $\left(\kappa_{2}\right)$, one obtains

$\frac{d \eta}{d i}=\sqrt{\frac{\mathrm{RT}}{\mathrm{nFSi}_{0} \mathrm{~K}_{2}}}$

which is valid also for the anode under the following conditions:

- The external agglomerate surface area $S$, was estimated to be $2.7 \cdot 10^{5} \mathrm{~m}^{-1}$, by assuming that the agglomerate are spherical and with a radius of $4 \mu \mathrm{m}$.

- Only the external surface of the agglomerates is accessible for the reaction.

- The porosity of the electrode was $64 \%$ and the pore electrolyte conductivity was assumed to be $5 \mathrm{~S} / \mathrm{m}$ at $650^{\circ} \mathrm{C}$

This means that at low overpotentials, where mass transfer limitations are assumed to be small, there is a proportional relationship between the current density and the overpotential. The exchange current density is a function of the partial pressure of the reactants according to

$\mathrm{i}_{\mathrm{O}}=\mathrm{i}_{0}^{0} \cdot \mathrm{p}_{\mathrm{H}_{2}}^{\mathrm{a}} \cdot \mathrm{p}_{\mathrm{CO}_{2}}^{\mathrm{b}} \cdot \mathrm{p}_{\mathrm{H}_{2} \mathrm{O}}^{\mathrm{c}}$ 
where $\mathrm{a}, \mathrm{b}$, and $\mathrm{c}$ are the partial pressure dependency for $\mathrm{H}_{2}, \mathrm{CO}_{2}$ and $\mathrm{H}_{2} \mathrm{O}$, respectively, and $i_{0}^{C_{-}}$is the standard exchange current density.

\section{RESULTS AND DISCUSSION}

The reaction orders were calculated by solving the over-determined system (4). The same reaction orders were found to be valid for the complete temperature range. In case I, the water content in all gases was close to that in the inlet gas (always 19.9\%) which made the reaction order of water more uncertain. The results are shown in Table 2. These reaction orders are rather high and therefore difficult to explain by the generally assumed mechanisms.

A commercial catalyst for the water-shift reaction was placed in the gas channel for cell no. 3 to facilitate the reaction. Tables 2 show the reaction orders for cell number 2 and 3 . They are similar to those obtained from cell number 1 though the cell performance was better for the last two cells (Fig. 1). This figure also shows that the performance was the same for cells no. 2 and 3 though the third cell had a commercial catalyst and no. 2 did not have any catalyst. These two cells showed almost the same performance for all the gases except that the temperature dependence was larger for the third cell.

The obtained exchange current density, for standard gas at $650^{\circ} \mathrm{C}$, is $70 \mathrm{~A} / \mathrm{m}^{2}$. The temperature dependence of the exchange current density is small with an activation energy of $40-65 \mathrm{~kJ} / \mathrm{mol}$. This value is in the same range as those reported by other authors $/ 8,15 /$.
Concluding this section, the obtained results could be used in cell and stack models for system simulations as well as for stack design. Further work is still necessary since our model gives a better description of the performance but still not the whole truth and not a perfect description of the cell performance under varying gas composition.

\section{CONCLUSIONS}

This study has gone some way towards understanding of the anode reaction in MCFC. It has highlighted a number of problem areas in existing theory and further research is still needed.

Almost the same reaction orders were found for cell no. 1-3 though the cell performance was better for the last two cells. However, they were rather high and therefore difficult to explain by the generally assumed mechanisms. The obtained exchange current density, for standard gas at $650^{\circ} \mathrm{C}$ is $70 \mathrm{~A} / \mathrm{m}^{2}$ and the activation energy is $40-65 \mathrm{~kJ} / \mathrm{mol}$.

\section{ACKNOWLEDGMENTS}

This work was financially supported by the Swedish National Energy Administration and the International Joint Research grant, NEDO (Japan). The laboratory cell unit and the cell components are purchased from ECN in the Netherlands.

Table 2

Partial pressure dependency on the exchange current density, $\mathrm{i}_{0}=\mathrm{i}_{0}^{0} \cdot \mathrm{P}_{\mathrm{H}_{2}}^{\mathrm{a}} \cdot \mathrm{P}_{\mathrm{CO}_{2}}^{\mathrm{b}} \cdot \mathrm{P}_{\mathrm{H}_{2} \mathrm{O}}^{\mathrm{c}} \cdot i_{0}$ is given at standard conditions i.e. $80 \% \mathrm{H}_{2} \& 20 \% \mathrm{CO}_{2}$ humidified at $60^{\circ} \mathrm{C}$. Operating temperature is $650^{\circ} \mathrm{C}$. The confidence interval is $95 \%$.

\begin{tabular}{|l|l|l|l|l|l|l|}
\hline & & $\mathrm{a}$ & $\mathrm{b}$ & $\mathrm{c}$ & $\mathrm{i}_{0}\left[\mathrm{~A} / \mathrm{m}^{2}\right]$ & $\mathrm{E}_{\mathrm{a}}[\mathrm{kJ} / \mathrm{mol}]$ \\
\hline Cell no.1 & Measured & $0.50+/-0.15$ & $0.50+/-0.22$ & $1.25+/-2.24$ & & \\
\hline & Equilibrium & $0.75+/-0.14$ & $0.62+/-0.13$ & $0.92+/-0.32$ & & \\
\hline Cell no.2 & Equilibrium & $0.50+/-0.21$ & $0.40+/-0.18$ & $0.88+/-0.94$ & 71 & $42+/-13$ \\
\hline Cell no.3 & Equilibrium & $0.60+/-0.17$ & $0.64+/-0.17$ & $0.55+/-0.23$ & 70 & $65+/-12$ \\
\hline
\end{tabular}




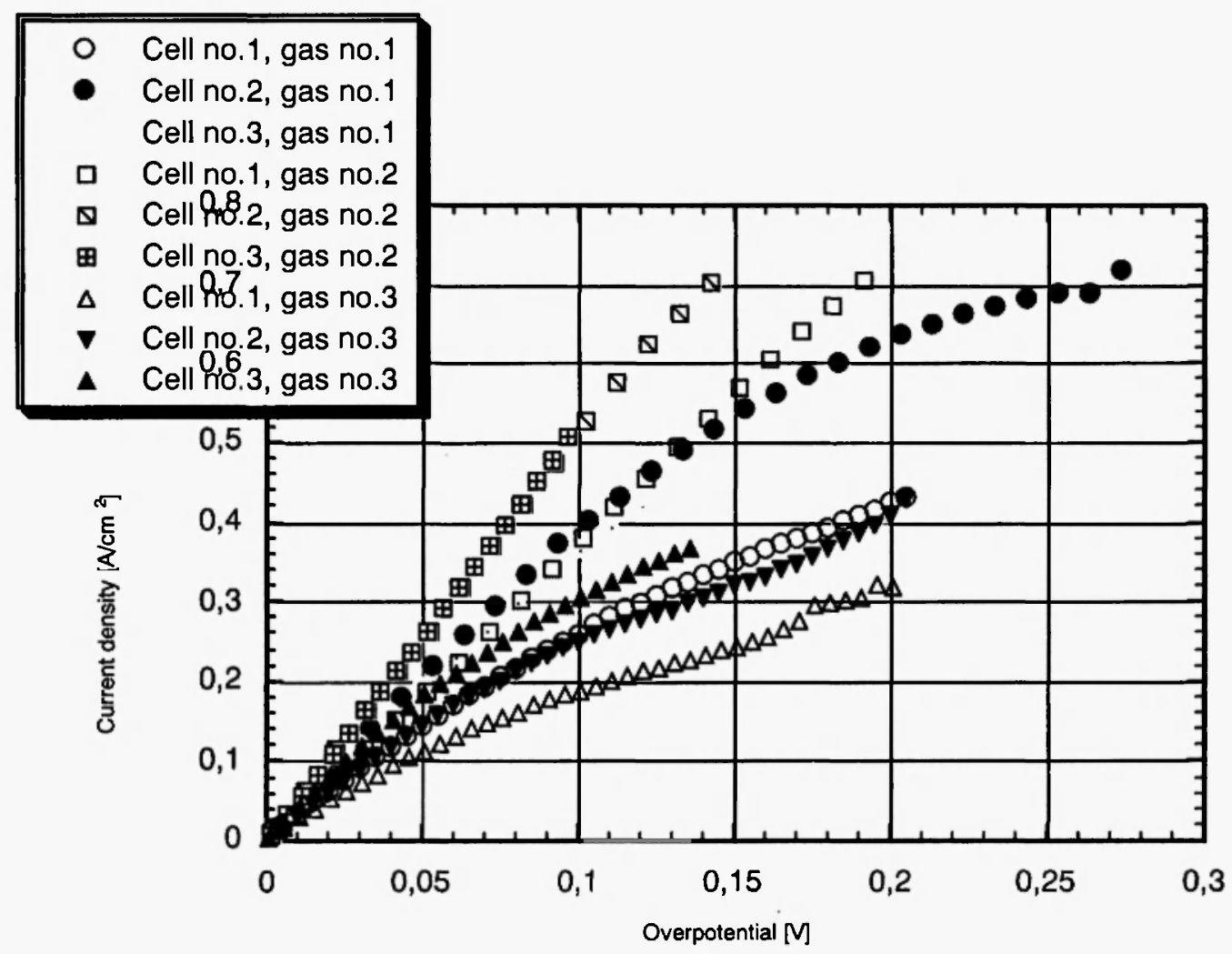

Fig. 1: Polarisation curves for the porous nickel anode at $650^{\circ} \mathrm{C}$ for different gas compositions. Gas no.1: $16 \% \mathrm{H}_{2}$, $32 \% \mathrm{CO}_{2}, 20 \% \mathrm{H}_{2} \mathrm{O}$ and $\mathrm{N}_{2}$, gas no. $2: 64 \% \mathrm{H}_{2}, 16 \% \mathrm{CO}_{2}$ and $20 \% \mathrm{H}_{2} \mathrm{O}$, gas no. $3: 6 \% \mathrm{H}_{2}, 67 \% \mathrm{CO}_{2}, 7 \% \mathrm{CO}$ and $20 \% \mathrm{H}_{2} \mathrm{O}$.

\section{LIST OF SYMBOLS}

F Faraday's constant [As/mol]

i current density $\left[\mathrm{A} / \mathrm{m}^{2}\right]$

$i_{0}$ exchange current density $\left[A / \mathrm{m}^{2}\right]$

$\mathrm{i}_{0}^{\mathrm{C}}$ standard exchange current density $\left[\mathrm{A} / \mathrm{m}^{2}\right]$

$\mathrm{L}$ electrode thickness $[\mathrm{m}]$

$\mathrm{n}$ number of electrons

R gas constant $[\mathrm{J} / \mathrm{mol} \mathrm{K}]$

$\mathrm{S}$ specific surface area $\left[\mathrm{m}^{-1}\right]$

$\mathrm{T}$ temperature [K]

\section{Greek letters}

$\varepsilon$ effectiveness factor

$\kappa_{1}$ conductivity in electrode phase [S/m]

$\kappa_{2}$ conductivity in electrolyte phase $[\mathrm{S} / \mathrm{m}]$

$\eta$ overpotential [V]

\section{REFERENCES}

1. P. G. P. Ang and A. F. Sammells, $J$ Electrochem. Soc., 127, 1287 (1980).

2. W. M. Vogel, L. J. Bregoli and S. W. Smith, J. Electrochem. Soc., 127, 833 (1980).

3. J. Jewulski and L. Suski, J. Appl. Electrochem, 14, 135 (1984).

4. S. H. Lu and J. R. Selman, J. Electrochem. Soc, 131, 2827 (1984).

5. S. H. Lu and J. R. Selman, J. Electrochem. Soc., 136, 1063 (1989).

6. S. H. Lu and J. R. Selman, J. Electrochem. Soc., 136, 1068 (1989).

7. C. Y. Yuh and J. R.Selman, J. Electrochem. Soc., 131, 2062 (1984).

8. C. Y. Yuh and J. R.Selman, J. Electrochem. Soc., 
138, 3642 (1991).

9. C. Y. Yuh and J. R.Selman, J. Electrochem. Soc., 138, 3649 (1991).

10. C. Y. Yuh and J. R.Selman, J. Electrochem. Soc., 139, 1373 (1992).

11. L. K. Bieniasz and L. Suski, J. Electroanal. Chem., 249, 155 (1988).

12. T. Nishina, M. Takahashi and I. Uchida, J. Electrochem. Soc.,137, 1112 (1990).

13. R. Weewer, R. C. Makkus, K. Hemmes and J. H. de Wit, J. Electrochem. Soc., 137, 3156 (1990).

14. R. Weewer, PhD thesis, The Netherlands, (1991).

15. R. Weewer, K. Hemmes and J. H. de Wit, J. Electrochem. Soc., 142, 389 (1995).

16. G. Wilemski, J. Electrochem. Soc., 130, 117
(1983).

17. L. Suski, Polish J. Chem., 71, 407 (1997).

18. P. S. Christensen and H. Livbjerg, Chemical Engineering Science, 47, 2933 (1992).

19. A. J. Appleby and A. Borucka, J. Chem. Soc., Faraday Trans. 1, 73, 1420 (1977).

20. S. H. Clarke et al., Catalysis Today, 38, 411 (1997).

21. C. Lagergren, A. Lundblad and B. Bergman, $J$. Electrochem. Soc., 141, 2959 (1994).

22. C. Lagergren and D. Simonsson, J. Electrochem. Soc., 144, 3813 (1997).

23. Y. Magikura and J. R. Selman, J. Electrochem. Soc., 143, 2442 (1996). 